\title{
Synthesis and Antitumor Activity of (3-Hydroxyacrylato-O,O') Diammineplatinum(II)
}

\author{
Yong-Zhi Shu ${ }^{1,2}$ Jun Lin ${ }^{2}$ Bao-Quan Zhu ${ }^{2}$ Quan-Hai Liu ${ }^{2}$ Bin Zhou ${ }^{2}$ Hai-Feng Hü,* Dian-Wen Ju,*
}

${ }^{1}$ Department of Biological Medicines, School of Pharmacy, Fudan University, Shanghai, People's Republic of China

2 State Key Laboratory of New Drug and Pharmaceutical Process, Shanghai Institute of Pharmaceutical Industry, China State Institute of Pharmaceutical Industry, Shanghai, People's Republic of China

Pharmaceut Fronts 2021;3:e13-e17.

\author{
Address for correspondence Hai-Feng Hu, PhD, State Key Laboratory \\ of New Drug and Pharmaceutical Process, Shanghai Institute of \\ Pharmaceutical Industry, 285 Gebaini Road, Shanghai 201203, \\ People's Republic of China (e-mail: haifenghu88@163.com).
}

Dian-Wen Ju, PhD, School of Pharmacy, Fudan University, 826 Zhangheng Road, Shanghai 201203, People's Republic of China (e-mail: dianwenju@fudan.edu.cn).
Abstract
Keywords
- platinum(II) complexes
- antitumor activity
- Michael acceptor

As an indispensable part of cancer chemotherapy, platinum drugs still play an important role in cancer treatment. In this study, two platinum(II) complexes with Michael acceptor 3-hydroxyacrylic acid as the leaving group were synthesized from cisdiamminediiodo platinum(II) and 3-ethoxyacrylic acid. The structures of complexes 1 and 2 were confirmed by elemental analysis, infrared, ${ }^{1} \mathrm{H}$ NMR, ${ }^{13} \mathrm{C}$ NMR, and HRMS (high-resolution mass spectrometry). Results from MTT assay showed that complexes 1 and 2 significantly inhibited the growth of the four human tumor cell lines (HCT-116, A549, CFPAC -1 , and BxPC-3) with the I $\mathrm{C}_{50}$ values of the two compounds similar to that of the control drug (oxaliplatin) on HCT-116 and A549. Besides, results from an in vivo study in a mouse $\mathrm{S} 180$ sarcoma model showed that complex 1 had a higher antitumor activity in comparison to oxaliplatin. In conclusion, our article indicated that complex 1 deserved further research and development in cancer treatment.

\section{Introduction}

Cisplatin, a platinum(II) complex, has made a major impact in the chemotherapeutic treatment of testicular and ovarian cancers since the accidental discovery of its biological activity, and is widely used in the treatment of these types of cancers. ${ }^{1,2}$ However, it still has nonnegligible toxic and side effects such as nephrotoxicity, emetogenicity, and drug resistance, which cripple its overall effectiveness in cancer therapy. ${ }^{3-6}$ For decades, thousands of platinum(II) complexes have been prepared in the hope of finding those with more tolerable toxicological profile and higher efficacy. ${ }^{7}$ These efforts have brought several new drugs (carboplatin, oxaliplatin, nedaplatin, and lobaplatin) into market, ${ }^{8-10}$ followed by several new complexes emerging in current clinical trials (-Fig. 1). ${ }^{11}$

With regard to most of the platinum(II) complexes, such as carboplatin and oxaliplatin, dicarboxylate plays a role as the leaving group in the mechanism of the interaction between platinum(II) complex and DNA, and in addition to platinum(II) complexes containing dicarboxylate as the leaving group, there are also platinum(II) complexes, such as nedaplatin and lobaplatin, containing $\alpha$-hydroxylcarboxylate as the leaving group, which will have more stronger antitumor activity. ${ }^{12}$ Thus, exploring a novel compound based on the structure of platinum(II) complexes containing $\alpha$-hydroxylcarboxylate may represent an promising strategy to improve the antitumor activity of the platinum(II) complexes. ${ }^{12}$

To the best of our knowledge, the synthesis of platinum(II) complexes with Michael acceptor as leaving groups has not been reported. Michael acceptor is the functional group in which the olefins or acetylenes conjugated to electronwithdrawing groups. The compounds with Michael acceptor are considered as a class of biologically active molecules received

April 2, 2021

accepted

April 21, 2021
DOI https://doi.org/ $10.1055 / \mathrm{s}-0041-1730956$ ISSN 2628-5088. (c) 2021. The Author(s).

This is an open access article published by Thieme under the terms of the Creative Commons Attribution License, permitting unrestricted use, distribution, and reproduction so long as the original work is properly cited. (https://creativecommons.org/licenses/by/4.0/)

Georg Thieme Verlag KG, Rüdigerstraße 14, 70469 Stuttgart, Germany 


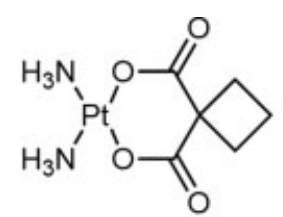

Carboplatin<smiles>N[P+]1(N)OCC(=O)O1</smiles>

Nedaplatin<smiles>O=C1O[P]2(N[C@H]3CCCC[C@H]3N2)OC1=O</smiles>

Oxaliplatin

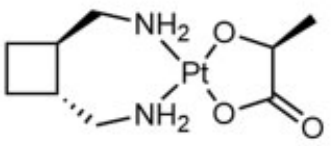

Lobaplatin

Fig. 1 Chemical structures of platinum drugs.

which directly or indirectly involved in the life processes. A series of studies suggested that the Michael acceptor moiety especially $\alpha, \beta$-unsaturated carbonyl fragment is the essential active group with cytotoxicity among various anticancer compounds. ${ }^{13-16}$ Michael acceptor is a fragment for covalent binding and might improve the nonselective cytotoxicity of platinum(II) complexes. In this study, two 3-hydroxyacrylatoplatinum(II) complexes containing Michael acceptors as leaving groups (complexes $\mathbf{1}$ and $\mathbf{2}$ ) were synthesized and characterized (-Fig. 2). Our data suggested the potential use of these two compounds in cancer treatment in the future.

\section{Results and Discussion}

\section{Successful Synthesis of Complexes 1 and 2}

Scheme $\mathbf{1}$ shows the synthesis of complexes $\mathbf{1}$ and $\mathbf{2}$ following a general method. ${ }^{17}$ Starting from cis-[PtR $\left.\mathrm{I}_{2}\right]$ (commercially available), the first step was performed in water with $\mathrm{AgNO}_{3}$ to form $\left[\mathrm{PtR}_{2}\left(\mathrm{H}_{2} \mathrm{O}\right)_{2}\right]\left(\mathrm{NO}_{3}\right)_{2}$. Furthermore, $\left[\mathrm{PtR}_{2}\left(\mathrm{H}_{2} \mathrm{O}\right)_{2}\right]\left(\mathrm{NO}_{3}\right)_{2}$ was mixed with sodium 3 -ethoxyacrylate to produce a yellow solution. The reaction mixture was concentrated in vacuum and purified by silica gel chromatography to obtain the target complex. The products were then characterized by elemental analysis, infrared (IR), ${ }^{1} \mathrm{H}$ NMR, ${ }^{13} \mathrm{C}$ NMR, mass spectrometry, and high-resolution mass spectrometry, respectively. The elemental analysis data for each compound were in good agreement with the designed structure formula. The binding of the 3-hydroxyacrylate to platinum atoms as a bidentate ligand was confirmed by the shift of $\mathrm{v}_{\mathrm{C}=\mathrm{O}}$ to lower frequencies and the absence of $v_{\mathrm{O}-\mathrm{H}}$ absorption in IR spectra in the resulting

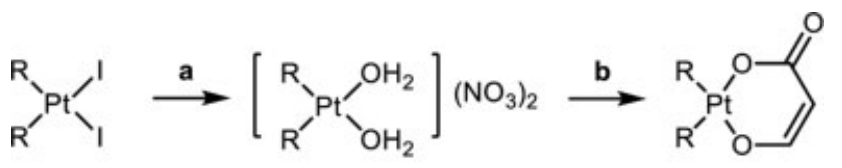

$\mathrm{R}=\mathrm{NH} 3$. Each $\mathrm{R}$ taken together forms $\mathrm{DACH}$

Scheme 1 Synthetic route for complexes 1 and 2. Reagents and conditions: a) $\mathrm{AgNO}_{3}, 60^{\circ} \mathrm{C}$, 4 hours; b) 3-ethoxyacrylic acid, $\mathrm{NaOH}$, $60^{\circ} \mathrm{C}, 3$ hours. DACH, trans-1,2-Diaminocyclohexane.<smiles>N[P+]1(N)OC=CC(=O)O1</smiles>

1<smiles>O=C1C=CO[Pb]2(N1)NC1CCCCC1N2</smiles>

2
Fig. 2 Chemical structures of platinum(II) complexes 1 and 2.

complexes. ${ }^{4}$ All complexes showed $[\mathrm{M}+\mathrm{H}]^{+}$peaks, corresponding to their molecular weights, and had three typical protonated molecular ion peaks reflecting the platinum isotopes: ${ }^{194} \mathrm{Pt}(33 \%),{ }^{195} \mathrm{Pt}(34 \%)$, and ${ }^{196} \mathrm{Pt}(25 \%) .{ }^{1} \mathrm{H}$ and ${ }^{13} \mathrm{C}$ NMR spectral peaks matched the chemical structures given in - Fig. 2. At room temperature, the solubility values of complexes 1 and $\mathbf{2}$ in phosphate buffered saline $(\mathrm{pH}=7.4)$ are 36.5 and $1.5 \mathrm{mg} / \mathrm{mL}$, respectively. Complex 1 possesses sufficient water solubility.

\section{An In Vitro Study Showing Cytotoxic Activities of Complexes 1 and 2 on Cancer Cells}

In this study, the in vitro cytotoxicity of the platinum(II) complexes was tested by measuring the effect of the complexes on the proliferation of the four cancer cells (the colorectal cancer cell line HCT-116, the lung carcinoma cell line A549, as well as the pancreatic cancer cell line CFPAC-1 and BxPC-3). These four cell lines were continuously exposed to different concentrations of oxaliplatin (serving as a control drug), as well as complexes $\mathbf{1}$ and $\mathbf{2}$ for 48 hours, and then $\mathrm{IC}_{50}$ of the three drugs was assessed using MTT assay according to a reported study. ${ }^{18}$-Table $\mathbf{1}$ shows that both complexes $\mathbf{1}$ and $\mathbf{2}$ showed cytotoxic activity on the four cell lines with the significant effect being seen in HCT-116 and A549 cells. Interestingly, the cytotoxicity of complex $\mathbf{1}$ was less and closer to that of the control drug when compared with complex 2 . Thus, we chose complex $\mathbf{1}$ for the following study.

\section{Complex 1 Inhibited Tumor Growth in a Mouse S180 Sarcoma Model}

The antitumor activities of complex $\mathbf{1}$ and oxaliplatin were further compared in a mouse S180 sarcoma model. ${ }^{19}$ Based on preliminary studies, tumor-bearing mice were administered with intraperitoneal injection of complex $\mathbf{1}(25 \mathrm{mg} / \mathrm{kg})$ oncedaily. - Table 2 shows that complex 1 displayed a strong antitumor effect (tumor growth inhibition: 69.78\%). However, administration of complex $\mathbf{1}$ also led to severe mouse weight loss, suggesting that the mice could not tolerate once-a-day

Table 1 In vitro cytotoxicity of complexes 1 and 2 against tumor cell lines

\begin{tabular}{|l|l|l|l|l|}
\hline & \multicolumn{4}{|l|}{$\mathrm{IC}_{\mathbf{5 0}}(\boldsymbol{\mu \mathrm { mol } / \mathrm { L } )}$} \\
\cline { 2 - 5 } & HCT-116 & A549 & CFPAC-1 & BxPC-3 \\
\hline Oxaliplatin & 39.22 & 45.28 & 43.97 & 31.81 \\
\hline Complex 1 & 35.34 & 43.46 & 92.39 & 69.05 \\
\hline Complex 2 & 15.05 & 28.94 & 66.18 & 94.50 \\
\hline
\end{tabular}


Table 2 Antitumor activity of complex 1 in mouse S180 sarcoma models ${ }^{\mathrm{a}}$

\begin{tabular}{|c|c|c|c|c|c|c|}
\hline \multirow[t]{2}{*}{ Group } & \multirow{2}{*}{$\begin{array}{l}\text { Dose } \\
(\mathrm{mg} / \mathrm{kg})\end{array}$} & \multirow[t]{2}{*}{ Dosing regimen } & \multicolumn{2}{|c|}{ Mean body weight (g) } & \multirow[t]{2}{*}{ Tumor weight (g) } & \multirow[t]{2}{*}{ TGI (\%) } \\
\hline & & & D1 & D7 & & \\
\hline Control & Vehicle & once-daily & $18.88 \pm 0.97$ & $21.45 \pm 1.83$ & $3.21 \pm 0.33$ & 1 \\
\hline Complex 1 & 25 & once-daily & $19.21 \pm 0.94$ & $15.44 \pm 0.90$ & $0.97 \pm 0.35$ & $69.78^{* *}$ \\
\hline
\end{tabular}

Abbreviation: TGI, tumor growth inhibition.

${ }^{a}$ Tumor-bearing mice were treated by intraperitoneal (ip) injection of complex 1 for 7 days. Data are presented as mean \pm SD. The comparison between the two groups was conducted using t-test with statistically significant at ${ }^{* *} p<0.01$ versus control.

Table 3 Different dose and dosing regimens on antitumor effect of complex 1 in mouse S180 sarcoma models ${ }^{\mathrm{a}}$

\begin{tabular}{|c|c|c|c|c|c|c|}
\hline \multirow[t]{2}{*}{ Group } & \multirow[t]{2}{*}{ Dose $(\mathrm{mg} / \mathrm{kg})$} & \multirow[t]{2}{*}{ Dosing regimen } & \multicolumn{2}{|c|}{ Mean body weight $(\mathrm{g})$} & \multirow[t]{2}{*}{ Tumor weight (g) } & \multirow[t]{2}{*}{ TGI (\%) } \\
\hline & & & D1 & D11 & & \\
\hline Control & Vehicle & Once-daily & $21.18 \pm 0.91$ & $24.08 \pm 3.32$ & $2.95 \pm 0.38$ & 1 \\
\hline Complex 1 & 15 & Once-daily & $20.94 \pm 0.64$ & $18.82 \pm 1.08$ & $1.66 \pm 0.39$ & $43.58^{* *}$ \\
\hline Complex 1 & 30 & Once in 2 days & $20.86 \pm 1.13$ & $20.21 \pm 3.22$ & $1.60 \pm 0.35$ & $45.87^{* *}$ \\
\hline Oxaliplatin & 9 & Once in 2 days & $21.14 \pm 1.04$ & $17.46 \pm 1.85$ & $1.18 \pm 0.24$ & $59.85^{\text {** }}$ \\
\hline
\end{tabular}

Abbreviation: TGl, tumor growth inhibition.

aTumor-bearing mice were treated by intraperitoneal (ip) injection of complex 1 for 11 days. Data are presented as mean \pm SD. The comparison between the two groups was conducted using $t$-test with statistically significant at ${ }^{* *} p<0.01$ versus control.

administration of complex $\mathbf{1}$, and the safe and effective dosage regimen should be explored.

\section{Increased Drug Given Dose and Extended Drug Given Interval May Enhance Antitumor Effect While Reducing Toxicity of Complex 1 in Mouse Xenograft Models}

Based on the results obtained from - Fig. 2, we further assessed whether decreasing complex 1 dose $(15 \mathrm{mg} / \mathrm{kg}$, once-daily) or prolonging its dosing interval $(30 \mathrm{mg} / \mathrm{kg}$, once in 2 days) will improve the effect of complex 1 on mouse body weight and tumor weight. - Table 3 shows the antitumor effect of complex $\mathbf{1}$ when administered at $30 \mathrm{mg} / \mathrm{kg}$; once in 2 days was more effective than daily dose at $15 \mathrm{mg} / \mathrm{kg}$, while the mouse weight loss of the complex was less severe. Interestingly, although the antitumor effect of complex 1 (30 mg/kg, once in 2 days) was weaker than the control drug (oxaliplatin, $9 \mathrm{mg} / \mathrm{kg}$ ) at a same dose interval (once in 2 days), the toxicity of compound $\mathbf{1}$ was significantly reduced.

Then, we further increased drug dose and extended drug dosing interval, and investigated whether a more effective and safer use of compound $\mathbf{1}$ would be achieved when compared with the control drug (oxaliplatin, $9 \mathrm{mg} / \mathrm{kg}$, once in 2 days). Thus, the drug dosing interval was increased to once in 3 days $(60 \mathrm{mg} / \mathrm{kg}$ ) or once in 6 days $(120 \mathrm{mg} / \mathrm{kg})$ in the mouse xenograft models. As shown in - Table 4, bolus application of compound 1, both $60 \mathrm{mg} / \mathrm{kg}$, once in 3 days, and $120 \mathrm{mg} / \mathrm{kg}$, once in 6 days, exhibited stronger antitumor activity than oxaliplatin with mouse weight being preserved even on 11th day, suggesting better safety profile of a larger dose at a longer interval of complex $\mathbf{1}$ at the two dosage regimens. Interestingly, a single bolus of complex $\mathbf{1}$ at $120 \mathrm{mg} / \mathrm{kg}$ once in 6 days gave the best result.

\section{Conclusion}

In summary, two 3-hydroxyacrylatoplatinum(II) complexes with novel six-membered ring structures containing Michael acceptors as leaving groups were synthesized and characterized. Both complexes $\mathbf{1}$ and $\mathbf{2}$ were evaluated for cytotoxicity against four human cancer cell lines and complex 1 was evaluated for antitumor activity in a mouse S180 xenograft

Table 4 In vivo antitumor activity of complex 1 in mouse S180 sarcoma models with the improved drug administration ${ }^{\text {a }}$

\begin{tabular}{|c|c|c|c|c|c|c|}
\hline \multirow[t]{2}{*}{ Group } & \multirow[t]{2}{*}{ Dose $(\mathrm{mg} / \mathrm{kg})$} & \multirow[t]{2}{*}{ Dosing regimen } & \multicolumn{2}{|c|}{ Mean body weight $(\mathrm{g})$} & \multirow[t]{2}{*}{ Tumor weight (g) } & \multirow{2}{*}{$\begin{array}{l}\text { TGI } \\
\text { (\%) }\end{array}$} \\
\hline & & & D1 & D11 & & \\
\hline Control & Vehicle & Once in 3 days & $22.81 \pm 1.17$ & $24.56 \pm 3.67$ & $3.08 \pm 0.32$ & 1 \\
\hline Complex 1 & 60 & Once in 3 days & $22.21 \pm 0.73$ & $22.46 \pm 2.28$ & $1.10 \pm 0.56$ & $64.39^{* *}$ \\
\hline Complex 1 & 120 & Once in 6 days & $22.78 \pm 0.75$ & $20.34 \pm 2.44$ & $1.02 \pm 0.36$ & $66.83^{* *}$ \\
\hline Oxaliplatin & 9 & Once in 2 days & $23.18 \pm 0.62$ & $19.92 \pm 2.50$ & $1.16 \pm 0.20$ & $62.42^{* *}$ \\
\hline
\end{tabular}

Abbreviation: TGl, tumor growth inhibition.

a Tumor-bearing mice were treated by intraperitoneal (ip) injection of complex 1 for 11 days. Data are presented as mean \pm SD. The comparison between the two groups was conducted using $t$-test with statistically significant at ${ }^{* *} p<0.01$ versus control. 
model. The results showed that the anticancer effects of complexes $\mathbf{1}$ and $\mathbf{2}$ were similar to that of oxaliplatin in two human cancer cell lines. Furthermore, we explored the different dosing regimens of complex $\mathbf{1}$ in an in vivo study. Our data showed that administration of complex $\mathbf{1}$ at 120 $\mathrm{mg} / \mathrm{kg}$ once in 6 days was more efficacious and safer than the control drug (oxaliplatin). In conclusion, 3-hydroxyacrylatoplatinum(II) complexes with novel six-membered ring structures containing Michael acceptors (complexes $\mathbf{1}$ and 2) at a higher dose and a longer interval may serve as promising drug candidates in cancer therapy.

\section{Experimental Section}

(3-Hydroxyacrylato-0,0') diammineplatinum(II) (complex 1): To a solution of 3-ethoxylacrylic acid ( $1.0 \mathrm{~g})$ in water $(100 \mathrm{~mL})$ was added $\mathrm{NaOH}(340 \mathrm{mg})$. The solution was then shaken ultrasonically, adjusted to $\mathrm{pH}=7$ by $\mathrm{NaOH}$, and concentrated in vacuum. The residue was washed with water and $\mathrm{EtOH}$, respectively, to give the sodium 3-ethoxylacrylate (yellow solid, $1.15 \mathrm{~g}, 97.1 \%$ yield). cis-Diamminediiodo platinum(II) $(4.16 \mathrm{~g})$ was dissolved in water $(300 \mathrm{~mL}) . \mathrm{AgNO}_{3}$ $(2.92 \mathrm{~g}$, in $50 \mathrm{~mL}$ water) was added to the solution. The mixture was stirred for 4 hours at $50^{\circ} \mathrm{C}$ under darkness and filtered to remove the precipitate. To the filtrate was added sodium 3-ethoxylacrylate $(1.15 \mathrm{~g}$, in $100 \mathrm{~mL}$ water). The mixture was stirred for 4 hours at $65^{\circ} \mathrm{C}$ under darkness and filtered. The filtrate was concentrated in vacuum to remove most of the solvent. The residual solution $(\sim 15 \mathrm{~mL})$ was cooled to room temperature and filtered. The precipitate was respectively washed with water and EtOH twice and dried at $60^{\circ} \mathrm{C}$ to give complex $1(1.1 \mathrm{~g}$, white solid, $40.5 \%$ yield). Melting point: $185^{\circ} \mathrm{C}$ (decomp). Found (calcd. for $\mathrm{C}_{3} \mathrm{H}_{8} \mathrm{~N}_{2} \mathrm{O}_{3} \mathrm{Pt}$ ) C 11.12 (11.43), H 2.78 (2.56), N 8.54 (8.89). IR (KBr, v, cm $\left.{ }^{-1}\right): 3284(\mathrm{~s}), 1584(\mathrm{~s}), 1521(\mathrm{~s}), 1437(\mathrm{~s}), 1347$ (m), 1287 (vs). ${ }^{1} \mathrm{H}$ NMR (DMSO, $\left.400 \mathrm{MHz}\right): \delta_{\mathrm{H}}=4.14(\mathrm{~d}$, $J=6 \mathrm{~Hz}, 1 \mathrm{H}, \mathrm{OCH}), 6.55$ (d, $J=6 \mathrm{~Hz}, 1 \mathrm{H}, \mathrm{CCH}), 3.92(\mathrm{brs}, 3 \mathrm{H}$, $\mathrm{NH}_{3}$ ), 3.82 (brs, $\left.3 \mathrm{H}, \mathrm{NH}_{3}\right) .{ }^{13} \mathrm{C}$ NMR $\left(100 \mathrm{MHz}, \mathrm{CD}_{3} \mathrm{OD}\right)$ : $\delta_{\mathrm{C}}=165.8(\mathrm{C}=0), 164.7(\mathrm{CH}), 95.7(\mathrm{CH}) . \mathrm{MS}(\mathrm{ESI}): \mathrm{m} / z[\mathrm{M}+$ $\mathrm{H}]^{+}=316.11$. HR MS (ESI): calcd. $\mathrm{C}_{3} \mathrm{H}_{8} \mathrm{~N}_{2} \mathrm{O}_{3} \mathrm{Pt}[\mathrm{M}+\mathrm{H}]^{+}$ 316.0261, found 316.0263.

(3-Hydroxyacrylato-0,0')trans-cyclohexane-1,2-diamineplatinum(II) (complex 2): To a solution of 3-ethoxyl acrylic acid $(1.0 \mathrm{~g})$ in water $(100 \mathrm{~mL})$ was added $\mathrm{NaOH}$ (340 mg). The solution was shaken ultrasonically, adjusted to $\mathrm{pH}=7$ by $\mathrm{NaOH}$, and concentrated in vacuum. The residue was washed with water and EtOH respectively to give the sodium 3-ethoxylacrylate (yellow solid, $1.16 \mathrm{~g}, 97.5 \%$ yield). cis-Diiodo-(trans-(-)-1,2-diaminocyclohexane)platinum(II) $(3.40 \mathrm{~g})$ was dissolved in water $(300 \mathrm{~mL}) . \mathrm{AgNO}_{3}(1.46 \mathrm{~g}$ in $50 \mathrm{~mL}$ water) was added to the solution. The mixture was stirred for 5 hours at $55^{\circ} \mathrm{C}$ under darkness and filtered to remove the precipitate. To the filtrate was added sodium 3ethoxylacrylate (1.16 g in $100 \mathrm{~mL}$ water). The mixture was stirred for 5 hours at $60^{\circ} \mathrm{C}$ under darkness and filtered. The filtrate was concentrated in vacuum to remove most of the solvent. The residual solution $(\sim 15 \mathrm{~mL})$ was purified by a reversed-phase silica gel (eluted by a mixture of $\mathrm{MeOH}$ : water $=1: 9$ ). The eluent was collected and concentrated in vacuum to give a white solid. The white solid was dried at $60^{\circ}$ $C$ under darkness to give the complex $2(0.73 \mathrm{~g}$, white solid, $30.5 \%$ yield). Melting point: $208^{\circ} \mathrm{C}$ (decomp). Found (calcd. for $\mathrm{C}_{9} \mathrm{H}_{16} \mathrm{~N}_{2} \mathrm{O}_{3} \mathrm{Pt}$ ) C 26.95 (27.34), $\mathrm{H} 4.05$ (4.08), N 6.97(7.09). IR (KBr, v, cm $\left.{ }^{-1}\right): 3221(\mathrm{~m}), 2939(\mathrm{~m}), 1588$ (vs), 1426(m), $1340(\mathrm{~m}), 1297(\mathrm{~m}) .{ }^{1} \mathrm{H}$ NMR (DMSO, $\left.400 \mathrm{MHz}\right): \delta_{\mathrm{H}}=4.13(\mathrm{~d}$, $J=6 \mathrm{~Hz}, 1 \mathrm{H}, \mathrm{OCH}), 6.64(\mathrm{~d}, J=6 \mathrm{~Hz}, 1 \mathrm{H}, \mathrm{CCH}), 0.98-1.22(\mathrm{~m}$, $4 \mathrm{H}, \quad \mathrm{CH}_{2} \mathrm{CH}_{2} \mathrm{CH}_{2} \mathrm{CH}_{2}$ of DACH $), \quad 1.45-1.47 \quad(\mathrm{~m}, \quad 2 \mathrm{H}$, $\mathrm{CH}_{2} \mathrm{CH}_{2} \mathrm{CH}_{2} \mathrm{CH}_{2}$ of DACH), $1.80-1.83$ (m, $2 \mathrm{H}, \mathrm{CH}_{2} \mathrm{CH}_{2} \mathrm{CH}_{2} \mathrm{CH}_{2}$ of DACH), 2.11 (s, $2 \mathrm{H}, 2 \times \mathrm{CHNH}_{2}$ ), 5.00 (brs, $2 \mathrm{H}, \mathrm{NH}_{2}$ ), 5.56 (brs, $\left.2 \mathrm{H}, \mathrm{NH}_{2}\right) \cdot{ }^{13} \mathrm{C}$ NMR $\left(100 \mathrm{MHz}, \mathrm{CD}_{3} \mathrm{OD}\right): \delta_{\mathrm{C}}=165.7(\mathrm{C}=$ O), $164.9(\mathrm{CH}), 95.7(\mathrm{CH}), 62.1(\mathrm{CH}), 61.8(\mathrm{CH}), 31.9\left(2 \times \mathrm{CH}_{2}\right)$, $24.2\left(2 \times \mathrm{CH}_{2}\right) . \mathrm{MS}(\mathrm{ESI}): \mathrm{m} / z[\mathrm{M}+\mathrm{H}]^{+}=396.09$. HR MS (ESI): calcd. $\mathrm{C}_{9} \mathrm{H}_{12} \mathrm{~N}_{2} \mathrm{O}_{3} \mathrm{PtNa}[\mathrm{M}+\mathrm{Na}]^{+}$417.0685, found 417.0676.

Ethical Approval

In this study, the use of mice was approved by Animal Care and Use Committee of Shanghai Institute of Pharmaceutical Industry.

\section{Funding}

This work was supported by the Shanghai Innovation Action Plan of Science and Technology (Grant No. 14431905900). We thank Dr. MA Jing for support.

\section{Conflict of Interest}

None.

\section{References}

1 Kelland L. The resurgence of platinum-based cancer chemotherapy. Nat Rev Cancer 2007;7(08):573-584

2 Tchounwou PB, Dasari S, Noubissi FK, Ray P, Kumar S. Advances in our understanding of the molecular mechanisms of action of cisplatin in cancer therapy. J Exp Pharmacol 2021;13:303-328

3 Yao X, Panichpisal K, Kurtzman N, Nugent K. Cisplatin nephrotoxicity: a review. Am J Med Sci 2007;334(02):115-124

4 Imig JD, Hye Khan MA, Burkhan A, Chen G, Adebesin AM, Falck JR. Kidney-targeted epoxyeicosatrienoic acid analog, EET-F01, reduces inflammation, oxidative stress, and cisplatin-induced nephrotoxicity. Int J Mol Sci 2021;22(06):2793

5 Navari RM, Ruddy KJ, LeBlanc TW, et al. Avoidable acute care use associated with nausea and vomiting among patients receiving highly emetogenic chemotherapy or oxaliplatin. Oncologist 2021; 26(04):325-331

6 Zhao J, Tan W, Zhang L, et al. FGFR3 phosphorylates EGFR to promote cisplatin-resistance in ovarian cancer. Biochem Pharmacol 2021 (e-pub ahead of print). Doi: 10.1016/j.bcp.2021.114536

7 Jin S, Guo Y, Guo Z, Wang X. Monofunctional platinum(II) anticancer agents. Pharmaceuticals (Basel) 2021;14(02):133

8 Zhou J, Kang Y, Chen L, et al. The drug-resistance mechanisms of five platinum-based antitumor agents. Front Pharmacol 2020; $11: 343$

9 Dilruba S, Kalayda GV. Platinum-based drugs: past, present and future. Cancer Chemother Pharmacol 2016;77(06):1103-1124

10 Akshintala S, Marcus L, Warren KE, et al. Phase 1 trial and pharmacokinetic study of the oral platinum analog satraplatin in children and young adults with refractory solid tumors including brain tumors. Pediatr Blood Cancer 2015;62(04): 603-610

11 Wang X, Guo Z. Targeting and delivery of platinum-based anticancer drugs. Chem Soc Rev 2013;42(01):202-224 
12 Ye QS, Lou LG, Liu WP, et al. Synthesis and in vitro cytotoxicity of novel lipophilic (diamine)platinum(II) complexes of salicylate derivatives. Bioorg Med Chem Lett 2007;17(08): 2146-2149

13 Zhao QS, Cong YW. Michael reaction acceptor molecules in chemical biology. Huaxue Jinzhan 2007;19(12):1972-1976

14 Wijeratne EM, Bashyal BP, Liu MX, et al. Geopyxins A-E, entkaurane diterpenoids from endolichenic fungal strains Geopyxis aff. majalis and Geopyxis sp. AZ0066: structure-activity relationships of geopyxins and their analogues. J Nat Prod 2012;75(03): 361-369

15 Santagata S, Xu YM, Wijeratne EM, et al. Using the heat-shock response to discover anticancer compounds that target protein homeostasis. ACS Chem Biol 2012;7(02):340-349
16 Wang J, Yun D, Yao J, et al. Design, synthesis and QSAR study of novel isatin analogues inspired Michael acceptor as potential anticancer compounds. Eur J Med Chem 2018;144:493-503

17 Silva H, Barra CV, Rocha FV, Frezard F, Lopes MTP, Fontes APS. Novel platinum(II) complexes of long chain aliphatic diamine ligands with oxalato as the leaving group: comparative cytotoxic activity relative to chloride precursors. J Braz Chem Soc 2010;21 (10):1961-1967

18 Park DG. Antichemosensitizing effect of resveratrol in cotreatment with oxaliplatin in HCT116 colon cancer cell. Ann Surg Treat Res 2014;86(02):68-75

19 Liu W, Chen X, Xie M, et al. Synthesis and anticancer activity of [2hydroxy-1,3-diaminopropane-kappa $\left.2 \mathrm{~N}, \mathrm{~N}^{\prime}\right]$ platinum(II) complexes. J Inorg Biochem 2008;102(10):1942-1946 